\title{
Dietary lipid during the transition period to manipulate subcutaneous adipose tissue peroxisome proliferator-activated receptor-y co-regulator and target gene expression
}

\author{
E. Schmitt, ${ }^{\star 1}$ M. A. Ballou, $\dagger^{1}$ M. N. Correa, ${ }^{\star}$ E. J. DePeters, $\neq$ J. K. Drackley, $\S$ and J. J. Loor $\S^{2}$ \\ *Universidade Federal de Pelotas, NUPEEC, Departamento Clínicas Veterinária, Campus Universitário, 96010-900, Pelotas, \\ Rio Grande do Sul, Brazil \\ †Department of Animal and Food Science, Texas Tech University, Lubbock 79409 \\ ‡Department of Animal Science, University of California, Davis 95616 \\ $\S$ Department of Animal Sciences and Division of Nutritional Sciences, University of Illinois, Urbana 61801
}

\begin{abstract}
Objectives were to determine adipose tissue mRNA expression of peroxisome proliferator-activated receptor $(\mathrm{PPAR}) \gamma$ co-regulators, target enzymes and transcription regulators, inflammation-related genes, and adipokines in response to dietary long-chain fatty acids (LCFA). From -21 through $10 \mathrm{~d}$ relative to parturition cows were fed no supplemental LCFA (control), saturated LCFA (SFAT; mainly 16:0 and 18:0), or fish oil (FO). Lipid was fed at $250 \mathrm{~g} / \mathrm{d}$ prepartum or approximately 1.5 to $1.9 \%$ of the previous day's dry matter intake postpartum. Transcript profiling of 35 genes via quantitative PCR was conducted on biopsies $(\mathrm{n}=5$ cows/diet) collected at -14 and $11 \mathrm{~d}$ from parturition. Despite lower dry matter intake with FO, pre- and postpartal blood nonesterified fatty acids, $\beta$-hydroxybutyrate, and liver triacylglycerol were unaffected by treatment but increased after calving regardless of diet. Prepartal expression of adipogenic/ lipogenic transcription regulators $[C E B P A, C E B P B$, RXRA, KLF5, and MLXIPL (formerly ChREBP)] and co-regulators (CARM1, EP300, NCOA1, MED1, NCOR2, and NRIP1) was upregulated by FO and SFAT versus control, whereas most enzymes involved in lipogenesis/triacylglycerol synthesis (FASN, SCD, $D G A T 2$, and LPIN1) had greater expression only with FO. Expression of most adipogenic/lipogenic genes decreased after parturition, but feeding SFAT led to sustained upregulation of $C E B P A, C E B P B, R X R A$, several PPAR-co-activators, and DGAT2 and $S C D$, suggesting maintenance of a pro-adipogenic/pro-lipogenic state with SFAT. The co-activator $C R E B B P$ was greater in cows fed lipid and did not decrease after parturition, suggesting ligand activation of PPAR $\gamma$.
\end{abstract}

Received February 2, 2011.

Accepted August 27, 2011.

${ }^{1}$ These authors contributed equally.

${ }^{2}$ Corresponding author: jloor@illinois.edu
The greater peripartal expression of $N F K B 1$ and $T B K 1$ due to dietary lipid was suggestive of a local inflammatory response. At amounts fed prepartum, both FO and SFAT were effective in upregulating the adipose tissue PPAR $\gamma$-gene network. In contrast, only SFAT led to sustaining that response. Overall, the observed expression patterns are suggestive of an adipogenic regulatory mechanism particularly responsive to SFAT.

Key words: peroxisome proliferator-activated receptor, fat supplementation, insulin sensitivity

\section{INTRODUCTION}

The peripartal period is characterized by changes in gene network expression of metabolic and reproductive tissues (Wathes et al., 2009; Loor, 2010). Most research on the molecular adaptations in transition cows has focused on liver and mammary (reviewed in Loor, 2010) with little data available on adipose tissue (Lemor et al., 2009; Sumner-Thomson et al., 2011). In nonruminants, it is well-established that the nuclear receptor (NR) peroxisome proliferator-activated receptor (PPARG) $-\gamma$ is the master regulator of adipogenesis (Rosen and MacDougald, 2006). Peroxisome proliferator-activated receptor- $\gamma$ and its co-activator complex bind DNA as a heterodimer with retinoid X receptor- $\alpha$ (RXRA), and the heterodimer binds to specific motifs on the promoter region of target genes (Hsia et al., 2010). In 2 recent studies, daily i.v. injection of thiazolidinedione (TZD, a PPARG ligand) for the last 3 wk prepartum in dairy cows resulted in greater plasma insulin coupled with lower plasma NEFA during the peripartal period ( $\mathrm{d}-7$ through 7 postpartum; Smith et al., 2007, 2009). The lower NEFA could have been a response to greater insulin sensitivity of adipose tissue (Smith et al., 2007, 2009). Thus, it appears that bovine adipose tissue PPARG signaling around parturition could be altered by provision of exogenous ligands.

Nuclear receptor co-activators are characterized by their ability to enhance NR transactivation via interac- 
tion with the $\mathrm{N}$-terminal and the C-terminal ligandbinding domain of agonist-bound NR (Hsia et al., 2010). Gene knockout studies in nonruminants have clearly demonstrated roles for individual members of the PPAR family of co-regulators (Hsia et al., 2010). Activation of gene expression upon ligand binding to PPARG recruits nuclear receptor co-activator 1 (NCOA1), mediator complex subunit 1 (MED1), the co-activatorassociated proteins co-activator-associated arginine methyltransferase 1 (CARM1) and trimethylguanosine synthase 1 (TGS1), and the histone acetyltransferases CREB-binding protein (CREBBP) and E1A-binding protein 300 (EP300; Yu and Reddy, 2007). Adding to the complexity of the transcriptional regulation elicited by NR, the co-activators appear to bind, often in a promiscuous manner, to a variety of other NR [e.g., PPAR $\alpha$, thyroid hormone receptor $(\mathrm{TR} \alpha / \beta)$, estrogen receptor- $\alpha(\mathrm{ERR} \alpha)$, nuclear factor- $\kappa \mathrm{B}(\mathbf{N F} \kappa \mathbf{B})]$ and influence their function ( $\mathrm{Yu}$ and Reddy, 2007; Fritah et al., 2010).

In contrast to co-activators, co-repressors selectively repress NR-dependent gene transcription through interactions with unliganded or antagonist-bound (or in some cases, agonist-bound) NR on their target genes (Hsia et al., 2010). Nuclear receptor co-repressor 1 (NCOR1) and nuclear receptor co-repressor 2 (NCOR2) bind to unliganded PPAR and repress target-gene expression until ligand triggers their dismissal accompanied by recruitment of co-activators (Hsia et al., 2010). Other well-established repressors of PPARG include Krüppellike factor 2 (KLF2), nuclear receptor interacting protein 1 (NRIP1), and nuclear receptor subfamily 2, group F, member 2 (NR2F2), which appear to bind to the PPARG promoter region and decrease its expression and that of target genes (Rosen and MacDougald, 2006). For example, overexpression of NR2F2 in vitro led to diminished expression of PPARG, adiponectin (ADIPOQ), lipoprotein lipase (LPL), and fatty acidbinding protein 4 (FABP4), with an overall decrease in pre-adipocyte differentiation.

Because of the recognized importance of inflammatory pathways in adipocytes, current interest exists in establishing if inflammatory factors may mediate adipogenic transcriptional responses. Activity of interferon regulatory factor 3 (IRF3), which triggers the nuclear factor of kappa light polypeptide gene enhancer in Bcells 1 (NFKB1) signaling cascade during the innate immune response, is under tight regulation by inhibitor of kappa light polypeptide gene enhancer in B-cells, kinase epsilon (IKBKE) and TANK-binding kinase 1 (TBK1; Chau et al., 2008). Expression profiles of these immune-related molecules may provide evidence for the potential involvement of inflammation in bovine adipose adaptations to diet and physiological state. More importantly, the recent discovery that co-activators also play a role in regulation of $\mathrm{NF}_{\kappa} \mathrm{B}$ (Gao et al., 2005) signaling during inflammation raises the possibility of an even more complex level of regulation within adipose tissue.

The main objective of the present study was to evaluate the adipose tissue expression of PPAR co-regulators, target lipogenic enzymes, inflammation-related genes, target adipokines, and other transcription regulators (35 genes total) that may be responsive to different types of long-chain fatty acids (LCFA). To accomplish this objective, we profiled adipose tissue from cows fed a saturated lipid supplement or fish oil (FO) during the peripartal period (Ballou et al., 2009).

\section{MATERIALS AND METHODS}

\section{Experimental Design, Cows, and Diets}

Complete details of the animal experiment have been published previously (Ballou et al., 2009). Briefly, a completely random subset of 5 multiparous cows per treatment (second and third lactation) from the study of Ballou et al. (2009) that were fed no supplemental lipid (control, $\mathrm{n}=12$ cows total) or supplemental lipid from either Energy Booster (saturated LCFA, SFAT; Milk Specialties Co., Dundee, IL; $\mathrm{n}=15$ ) or FO (Omega Proteins, Houston, TX; $\mathrm{n}=15$ ) were used for transcript profiling. Although no power test to determine the number of cows for use in this study was performed, previous work dealing with gene expression in transition cows has shown that 4 to 8 cows are suitable to detect statistical significance in hepatic gene expression (Loor et al., 2006, 2007; Carriquiry et al., 2009) or tissue fatty acid profiles (Douglas et al., 2007). For cows used in this study, the control, FO, and SFAT diets were fed from $-25( \pm 4),-24( \pm 3)$, and $-26( \pm 7)$ $\mathrm{d}$, respectively, before expected date of parturition until $10 \mathrm{~d}$ after parturition. Treatments were fed as a bolus immediately before the a.m. feeding. The dose of lipid prepartum was $250 \mathrm{~g} / \mathrm{d}$, whereas the dose in the postpartum period was approximately 1.5 to $1.9 \%$ of the previous day's DMI. The composition of the bolus was $150 \mathrm{~g}$ each of rolled barley grain, shredded beet pulp, and cane molasses plus $550 \mathrm{~g}$ of the respective TMR plus the supplemental lipid source.

\section{Biopsies}

Prepartal liver and adipose biopsies were collected at $-14( \pm 4),-13( \pm 3)$, and $-16( \pm 6) \mathrm{d}$ in cows fed the control, FO, and SFAT, respectively. Time elapsed between the start of feeding and the first biopsy was, on average, $11( \pm 3)$ d. The postpartal biopsy was col- 
lected at $7( \pm 4)$ d postpartum. Prior to biopsies the hair on the tail-head and to one side of the tail-head was clipped closely and thoroughly scrubbed with surgical soap. Local anesthesia was applied over the area between the point of the ischium and coccygeal vertebra. A 6 to 8 -cm incision was made and the skin pulled back using sterile forceps, exposing the tissue. Samples were taken using a sterile scalpel blade and forceps. After the sample was taken, pressure was applied with sterile gauze to stop any external bleeding. The incision was closed with 8 to 12 surgical staples (\#89063337, Appose ULC Skin Stapler, 35 wide; Henry Schein Inc., Melville). Biopsied tissue (1 to $2 \mathrm{~g}$ ) was weighed and stored in liquid $\mathrm{N}_{2}$ before RNA extraction. The liver biopsy procedure was described by Ballou et al. (2009). A portion of liver tissue collected (0.8 to $1.0 \mathrm{~g})$ was analyzed for concentrations of total lipid, triacylglycerol, and glycogen as described by Ballou et al. (2009). Another portion of liver tissue was used for RNA extraction as described below.

\section{RNA Extraction, Primer Design and Evaluation, Internal Control Gene Evaluation, and Real-Time Quantitative PCR}

Complete details of these procedures can be found in Supplemental Materials (available at http://journalofdairyscience.org). Briefly, genes selected as suitable internal control gene (ICG) based on geNorm analysis included ACTB, GAPDH, SLC35A2, SERGEF, and $U X T$ for adipose; for liver, suitable ICG were $E D C 4$, SHPRH, EIF3K, UXT, ACTB, and MRPL39. The geometric mean of these genes was used to normalize gene expression data in the present study.

\section{Relative mRNA Abundance Among Transcripts Measured}

Relative mRNA abundance of measured genes was calculated as previously reported (Tramontana et al., 2008; Bionaz and Loor, 2011), using the inverse of PCR efficiency raised to median $\Delta$ cycle threshold $(\mathbf{C t})$ (gene abundance $=1 /$ efficiency $\left.^{(\text {median }} \Delta \mathrm{Ct}\right)$, where $\Delta \mathrm{Ct}=\mathrm{Ct}$ sample - geometric mean Ct of the ICG). Abundance of each target gene of interest relative to $U X T$ was calculated using the ratio of median $\Delta \mathrm{Ct}$ of the gene/ median $\Delta$ Ct of UXT. The UXT transcript was a gene with medium-to-low expression in our tissue samples (i.e., $\sim 26 \mathrm{Ct}$; see Supplemental Material, available at http://journalofdairyscience.org). Use of this technique for estimating relative mRNA abundance among genes was necessary because relative mRNA quantification was performed using a standard curve (made from a mixture of RNA from several bovine tissues), effectively precluding a direct comparison among genes (i.e., statistical analysis of these data are unwarranted). Together, the use of $\mathrm{Ct}$ values corrected for the efficiency of amplification and the ICG as baseline overcome this limitation. Description of genes measured and overall relative mRNA abundance is reported in Tables 2 and 3 .

\section{Blood Sampling and Metabolite and Plasma Fatty Acid Analysis}

These procedures have been reported by Ballou et al. (2009). Briefly, blood samples collected in evacuated tubes (Vacutainer; Becton, Dickinson and Co., Rutherford, NJ) containing K2 EDTA were used to harvest plasma after centrifugation at 1,200 $\times g$ for $15 \mathrm{~min}$ and stored at $-20^{\circ} \mathrm{C}$ until analyzed for total plasma fatty acid composition, glucose, NEFA, BHBA, and BUN, as described by Ballou et al. (2009). Only data for the cows used in transcript profiling were included in the present study.

\section{Statistical Analysis}

After normalization with the geometric mean of the ICG, the qPCR data from all treatments (prepartum and postpartum) were transformed to 0 (leaving the proportional difference between the biological replicates) by $\log -2$ transformation of the fold-change relative to the prepartal control diet. Thus, for the evaluation of prepartal differences in gene expression in cows fed FO or SFAT, we calculated the proportional change relative to the prepartal control diet. The same proportional change was calculated between postpartal control, SFAT, and FO relative to the prepartal control data. Those calculations resulted in a fold-change relative to prepartal control values. Those data were then log-2 transformed (to obtain $0 \pm$ proportional difference) before statistical analysis. This approach has been used previously by one of our laboratories (Invernizzi et al., 2010; Bionaz et al., 2011; Bionaz and Loor, 2011). Our approach also normalizes expression data before statistical analysis. A repeated measures model was fitted to gene expression and performance data using Proc MIXED in SAS (SAS Institute Inc., Cary, NC). The model consisted of time, treatment, and time $\times$ treatment interaction as fixed effects, as well as cow as the random effect. An autoregressive covariate structure was used. All means were compared using the PDIFF statement of SAS. Blood plasma fatty acids at $1 \mathrm{~d}$ postpartum from cows fed FO or SFAT were analyzed using a 1-way ANOVA with data collected prepartum (i.e., baseline, -24 to $-26 \mathrm{~d}$ relative to parturition) used as covariate. The model for analy- 
Table 1. Performance, blood, and liver tissue composition in cows fed $(\mathrm{n}=5 /$ treatment $)$ control, fish oil (FO), or saturated lipid (SFAT) during the peripartal period

\begin{tabular}{|c|c|c|c|c|c|c|c|}
\hline \multirow[b]{2}{*}{ Variable } & \multicolumn{3}{|c|}{ Treatment } & \multirow[b]{2}{*}{ SEM } & \multicolumn{3}{|c|}{$P$-value } \\
\hline & Control & FO & SFAT & & Diet & Time & $\mathrm{D} \times \mathrm{T}^{1}$ \\
\hline \multicolumn{8}{|l|}{ DMI, kg/d } \\
\hline Prepartum ${ }^{2}$ & $16.3^{\mathrm{a}}$ & $13.4^{\mathrm{b}}$ & $15.9^{\mathrm{a}}$ & 0.83 & 0.05 & 0.01 & 0.42 \\
\hline Postpartum $^{3}$ & $20.7^{\mathrm{a}}$ & $16.0^{\mathrm{b}}$ & $19.6^{\mathrm{ab}}$ & 1.60 & 0.12 & 0.01 & 0.01 \\
\hline Milk, ${ }^{4} \mathrm{~kg} / \mathrm{d}$ & $43.3^{\mathrm{a}}$ & $35.0^{\mathrm{b}}$ & $44.8^{\mathrm{a}}$ & 1.60 & 0.01 & 0.01 & 0.56 \\
\hline \multicolumn{8}{|l|}{ Blood } \\
\hline \multicolumn{8}{|l|}{ Prepartum } \\
\hline NEFA, $\mu \mathrm{Eq} / \mathrm{L}$ & 224 & 214 & 247 & 40 & 0.74 & 0.01 & 0.99 \\
\hline $\mathrm{BHBA}, \mu M$ & 480 & 574 & 672 & 116 & 0.73 & 0.14 & 0.93 \\
\hline Glucose, $\mathrm{mg} / \mathrm{dL}$ & 56 & 55 & 55 & 2.0 & 0.86 & 0.06 & 0.13 \\
\hline BUN, mg/dL & 9 & 10 & 11 & 0.9 & 0.42 & 0.14 & 0.14 \\
\hline \multicolumn{8}{|l|}{ Postpartum } \\
\hline NEFA, $\mu \mathrm{Eq} / \mathrm{L}$ & 932 & 719 & 957 & 232 & 0.64 & 0.01 & 0.28 \\
\hline BHBA, $\mu M$ & 1,378 & 1,684 & 1,115 & 681 & 0.67 & 0.04 & 0.19 \\
\hline Glucose, $\mathrm{mg} / \mathrm{dL}$ & 45 & 48 & 47 & 3.2 & 0.78 & 0.01 & 0.48 \\
\hline BUN, mg/dL & 10 & 13 & 11 & 0.9 & 0.19 & 0.01 & 0.43 \\
\hline \multicolumn{8}{|l|}{ Liver, $\%$ wet weight } \\
\hline \multicolumn{8}{|l|}{ Prepartum } \\
\hline $\mathrm{TAG}^{5}$ & 0.23 & 0.25 & 0.29 & 0.11 & 0.77 & 0.33 & 0.04 \\
\hline Glycogen & $3.48^{\mathrm{b}}$ & $2.91^{\mathrm{c}}$ & $4.29^{\mathrm{a}}$ & 0.33 & 0.03 & 0.69 & 0.22 \\
\hline \multicolumn{8}{|l|}{ Postpartum } \\
\hline TAG & 3.14 & 4.47 & 4.30 & 2.25 & 0.82 & 0.11 & 0.95 \\
\hline Glycogen & 1.65 & 1.17 & 1.36 & 0.40 & 0.67 & 0.17 & 0.72 \\
\hline
\end{tabular}

${ }^{a-c}$ Means within a row with different superscript letters denote significant differences $(P<0.05)$.

${ }^{1}$ Diet $\times$ time interaction.

${ }^{2}$ Average of $\mathrm{d}-21$ through -1 prepartum.

${ }^{3}$ Average of $\mathrm{d} 1$ through 10 postpartum.

${ }^{4}$ Average of $\mathrm{d} 7$ and 14 postpartum.

${ }^{5}$ Triacylglycerol.

sis of plasma fatty acids included diet as the fixed effect and cow as the random effect.

\section{RESULTS}

\section{Performance}

Performance of cows is presented in Table 1. Cows fed FO had lower DMI during both the pre- and postpartal period. In addition, milk production at 7 and 14 DIM was lower due to FO. No influence of supplemental lipid was observed on any blood metabolites evaluated.

\section{Blood Plasma Fatty Acid Concentration}

A tendency $(P=0.11)$ was found for lower concentration of 18:0 in blood plasma due to feeding FO versus SFAT, which partly explains the significantly lower $(P$ $<0.05)$ concentration of cis9-18:1 at $1 \mathrm{~d}$ postpartum $(P<0.05$; Table 2$)$. In contrast, FO resulted in greater concentration of trans11-18:1, 20:5n3, and 22:5n3. Feeding SFAT, however, led to greater concentrations of $18: 3 \mathrm{n} 6,20: 3 \mathrm{n} 6$, and $22: 4 \mathrm{n} 6$.

\section{Transcription Regulators}

As indicated in the statistical analysis section, all normalized gene expression data were expressed relative to the prepartal control diet before statistical analysis [i.e., positive values denote greater expression and negative values lower expression for a given dietary treatment (control, FO, or SFAT) vs. the control diet either prepartum or postpartum]. Prepartal expression of $C E B P A, C E B P B$, and KLF5 was greater (diet $\times$ time, $P<0.05)$ in cows fed FO or SFAT compared with the controls (Table 2). Among lipid supplements, feeding FO led to greater (diet $\times$ time, $P<0.05$ ) prepartal expression of INSIG1 and $R X R A$ relative to cows fed SFAT or controls (Table 2), whereas feeding SFAT resulted in lower (diet $\times$ time, $P<0.05) S R E B F 1$ than both FO or controls but greater $R X R A$ than controls.

In contrast to prepartal responses, postpartal responses to dietary FO resulted in marked downregulation (diet $\times$ time, $P<0.05$ ) in expression of INSIG1, $P P A R G, S R E B F 1$, and THRSP compared with the control or SFAT (Table 2). Similar postpartal expression in response to the control or SFAT was observed for 
Table 2. Blood plasma fatty acid profiles (\% of total fatty acids) at $\mathrm{d} 1$ postpartum in cows fed $(\mathrm{n}=5 /$ treatment) fish oil (FO) or saturated lipid (SFAT) during the peripartal period

\begin{tabular}{|c|c|c|c|c|c|c|}
\hline \multirow[b]{2}{*}{ Fatty acid } & \multirow[b]{2}{*}{ Baseline $^{1}$} & \multirow[b]{2}{*}{ SEM } & \multicolumn{2}{|c|}{ d 1 postpartum } & \multirow[b]{2}{*}{ SEM } & \multirow[b]{2}{*}{$P$-value } \\
\hline & & & SFAT & FO & & \\
\hline $16: 0$ & 16.1 & 0.52 & 19.1 & 20.7 & 0.73 & 0.37 \\
\hline cis9-16:1 & 0.47 & 0.05 & 0.76 & 1.27 & 0.29 & 0.21 \\
\hline 18:0 & 25.3 & 0.50 & 21.8 & 19.6 & 0.70 & 0.11 \\
\hline cis9-18:1 & 9.4 & 0.70 & 13.2 & 8.6 & 0.99 & 0.03 \\
\hline trans9-18:1 & 0.15 & 0.04 & 0.12 & 0.07 & 0.01 & 0.01 \\
\hline trans11-18:1 & 0.68 & 0.11 & 0.59 & 1.59 & 0.14 & 0.01 \\
\hline$\sum$ trans-18:1 & 1.52 & 0.17 & 1.34 & 3.02 & 0.20 & 0.001 \\
\hline $18: 2 \mathrm{n} 6$ & 22.9 & 1.32 & 22.0 & 19.8 & 1.13 & 0.43 \\
\hline 18:3n6 & 0.23 & 0.03 & 0.24 & 0.11 & 0.02 & 0.03 \\
\hline $20: 3 \mathrm{n} 6$ & 4.60 & 0.22 & 3.18 & 1.65 & 0.29 & 0.02 \\
\hline 20:4n6 & 5.51 & 0.22 & 4.96 & 5.54 & 0.45 & 0.61 \\
\hline $22: 4 \mathrm{n} 6$ & 1.08 & 0.13 & 0.86 & 0.17 & 0.08 & 0.01 \\
\hline $22: 5 \mathrm{n} 6$ & 0.28 & 0.02 & 0.22 & 0.38 & 0.05 & 0.16 \\
\hline 18:3n3 & 1.61 & 0.15 & 1.46 & 1.44 & 0.18 & 0.96 \\
\hline $20: 5 n 3$ & 0.66 & 0.15 & 0.56 & 3.45 & 0.25 & 0.001 \\
\hline $22: 5 \mathrm{n} 3$ & 1.96 & 0.16 & 1.87 & 2.45 & 0.18 & 0.14 \\
\hline $22: 6 \mathrm{n} 3$ & 0.30 & 0.06 & 0.28 & 2.75 & 0.11 & 0.001 \\
\hline Unknown & 2.94 & 0.56 & 3.24 & 3.39 & 0.74 & 0.71 \\
\hline Other & 4.50 & - & 4.20 & 4.00 & - & - \\
\hline
\end{tabular}

${ }^{1}$ Average of cows in SFAT and FO at enrollment. No statistical differences between groups were observed $(P$ $>0.10)$.

PPARG, SREBF1, and THRSP, whereas feeding SFAT resulted in greater (diet $\times$ time, $P<0.05) C E B P A$, $C E B P B, M L X I P L$, and $R X R A$ expression compared with controls.

\section{Nuclear Receptor Co-Activators}

Prepartal expression of CARM1, EP300, and NCOA1 was greater $($ diet $\times$ time, $P<0.05)$ in cows

Table 3. Relative mRNA expression ${ }^{1}$ of lipogenic transcription regulators, nuclear receptor co-activators, and co-repressors in adipose tissue of cows fed $(\mathrm{n}=5 /$ treatment) control, fish oil $(\mathrm{FO})$, or saturated lipid (SFAT) during the peripartal period

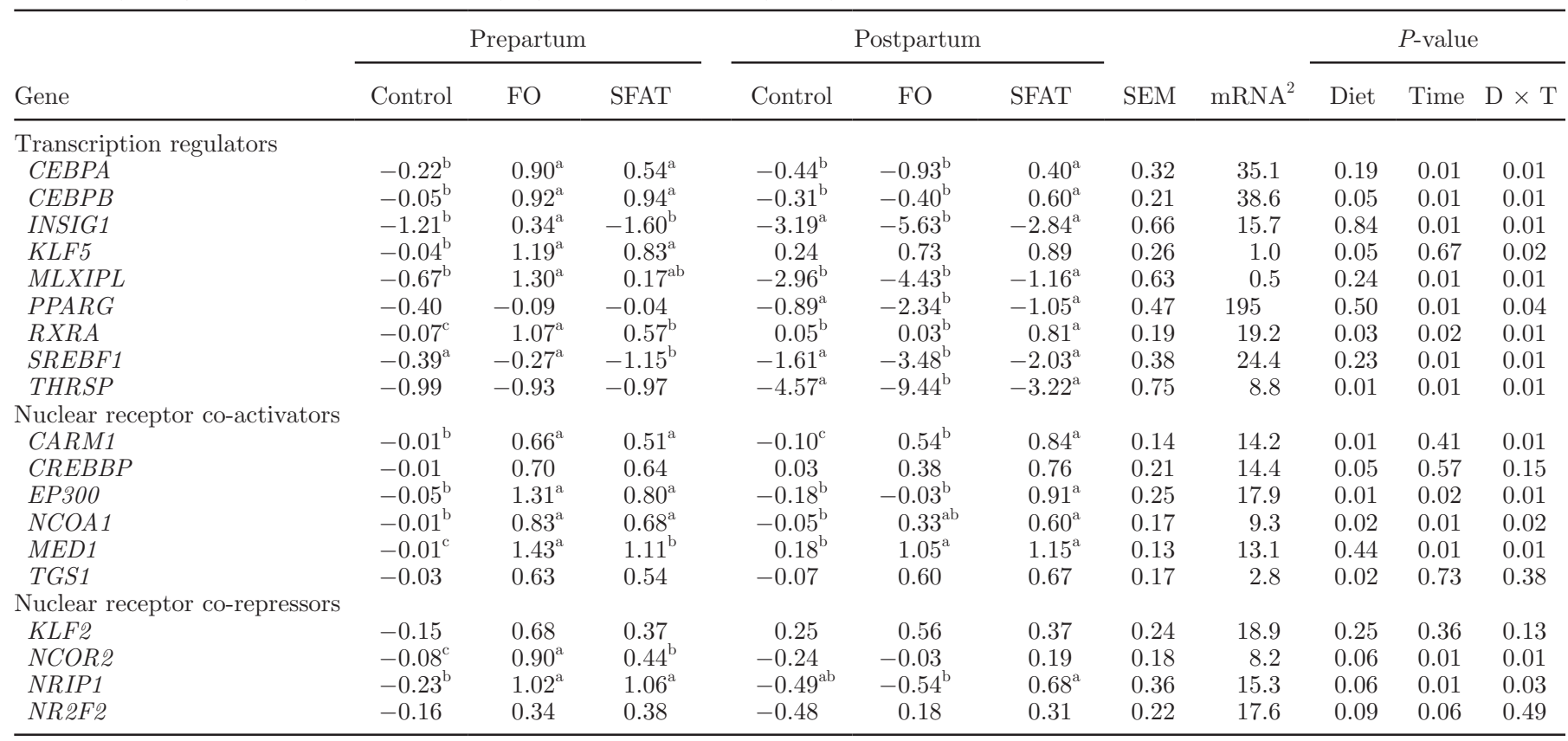

\footnotetext{
${ }^{\mathrm{a}-\mathrm{c}}$ Means within a row with different superscript letters denote significant interactions due to diet $\times$ time $(\mathrm{D} \times \mathrm{T})(P<0.05)$.

${ }^{1}$ Expression data are relative to the prepartal control value as described in Materials and Methods.

${ }^{2}$ The mRNA abundance was calculated relative to $U X T$ (see Materials and Methods). Abundance $=1 / \mathrm{E}^{(\text {median } \Delta \mathrm{Ct})}$, where $\mathrm{E}=$ efficiency and $\mathrm{Ct}=$ cycle threshold
} 
fed FO or SFAT compared with the controls (Table 2). Among lipid supplements, feeding FO led to the greatest expression (diet $\times$ time, $P<0.05$ ) of MED1, followed by SFAT relative to the controls. Postpartum, dietary SFAT led to greater expression (diet $\times$ time $P$ $<0.05)$ of CARM1, EP300, NCOA1, and MED1 compared with the control, whereas feeding $\mathrm{FO}$ resulted in greater (diet $\times$ time $P<0.05$ ) expression of CARM1 and MED1 compared with the control.

\section{Nuclear Receptor Co-Repressors}

Significant interactions were only observed for the expression of NRIP1 which was greater $(P<0.05)$ in response to feeding SFAT compared with the control or FO. An overall diet effect $(P<0.09)$ occurred for the expression of NCOR2 and NR2F2. The former was greater overall due to feeding FO and the latter due to feeding SFAT (Table 2).

\section{Lipogenic Enzymes}

Prepartal expression of DGAT2, FASN, LPIN1, and $S C D$ was greatest (diet $\times$ time, $P<0.05$ ) in cows fed FO, intermediate in cows fed SFAT, and lowest in cows fed the control (Table 3). Expression of $L P L$ was greater (diet $\times$ time, $P<0.05$ ) with FO and SFAT compared with control. Similar to what we observed for most transcription regulators and several co-regulators, dietary FO resulted in the lowest (diet $\times$ time $P<$ 0.05) postpartal expression of DGAT2, FABP $4, F A S N$, LPIN1, LPL, PCK1, and SCD (Table 3). Interestingly, both control and SFAT resulted in similar expression of FABP 4, FASN, LPIN1, LPL, and PCK1, whereas feeding SFAT resulted in the greatest expression of DGAT2 and $S C D$.

\section{Inflammation-Related Genes}

Among genes studied, prepartal expression of NFKB1 and TBK1 was greater (diet $\times$ time, $P<0.05$ ) in response to feeding FO or SFAT compared with the control (Table 3$)$. An overall diet effect $(P<0.05)$ was observed for the expression of $I K B K E$ due to greater responses in cows fed FO compared with the control.

\section{Adipokines and Hepatokines}

No significant effects of diet were observed for the prepartal expression of $A D I P O Q, A N G P T L 4$, and $L E P$ in adipose tissue (Figure 1). In liver, however, expression of $A D I P O R 2$ was lowest (diet $\times$ time, $P<0.05$ ) in response to feeding SFAT, intermediate with FO, and highest with control.
Postpartal expression of ANGPTL4 in adipose tissue was greater (diet $\times$ time, $P<0.05$ ) with SFAT than control or FO, whereas LEP expression was lower with FO and control compared with SFAT, and expression of $A D I P O Q$ was lower with FO compared with SFAT or control (Figure 1). In liver, ANGPTL4 expression was substantially greater (diet $\times$ time, $P<0.05$ ) in controls compared with either FO or SFAT. Expression of ADI$P O R 2$ in liver was greater (diet $\times$ time, $P<0.05$ ) with control versus FO and intermediate for SFAT.

\section{DISCUSSION}

\section{Performance, Blood Metabolites, and Plasma Fatty Acid Profiles}

Although performance data in the subset of cows used for transcript profiling differed from the data of Ballou et al. (2009) and do not constitute a representative sample of cows from the larger study, where DMI and milk production did not differ due to diet, previous work has shown that supplementing FO at 1.8 to $2.0 \%$ or fish meal at 1.25 or $2.5 \%$ of the diet DM to peripartal cows decreased DMI and milk production (Whitlock et al., 2002; Mattos et al., 2004; Heravi Moussavi et al., 2007). Therefore, the subsampled population used in the transcriptome analysis in the present study does represent a population where supplementing FO during the peripartal period decreases DMI and milk production. We found no differences in pre- and postpartal concentrations of metabolites in the subset of cows used, which was similar to the larger study by Ballou et al. (2009). A previous study with transition cows also did not find differences in postpartal blood (average of responses from 5 to 50 DIM) NEFA, BUN, or BHBA in response to supplemental fish meal (1.25 to $5 \%$ of DM; Heravi Moussavi et al., 2007). However, the fact that the level of fish meal fed probably did not provide oil at the levels we fed and the lack of apparent treatment effects on postpartal DMI complicate a direct comparison between studies.

Regarding SFAT, our prepartal and postpartal production and blood data agree with previous results from transition cows comparing saturated (Ca soap or Energy Booster) and unsaturated fat supplements at 4 to approximately 6\% of DM (Douglas et al., 2007; Andersen et al., 2008). However, they contrast with other observations showing that supplementation of Energy Booster at 1.7\% of DM prepartum and 3.7\% of DM from calving to 4 wk postpartum decreased DMI and increased postpartal blood NEFA, BHBA, and liver triacylglycerol substantially (Petit et al., 2007). Despite these differences, the overall responses in terms of blood NEFA and BHBA concentrations that we ob- 


\section{Adipose}
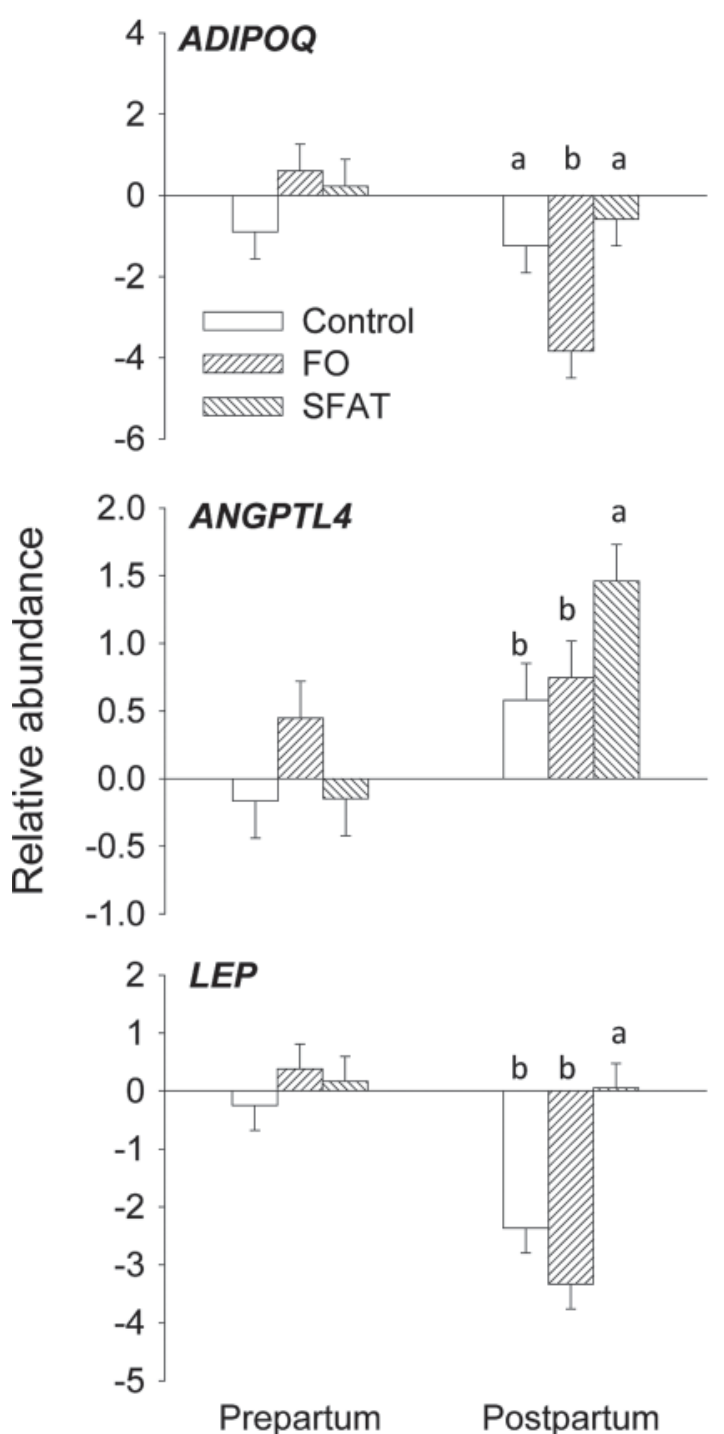

Liver
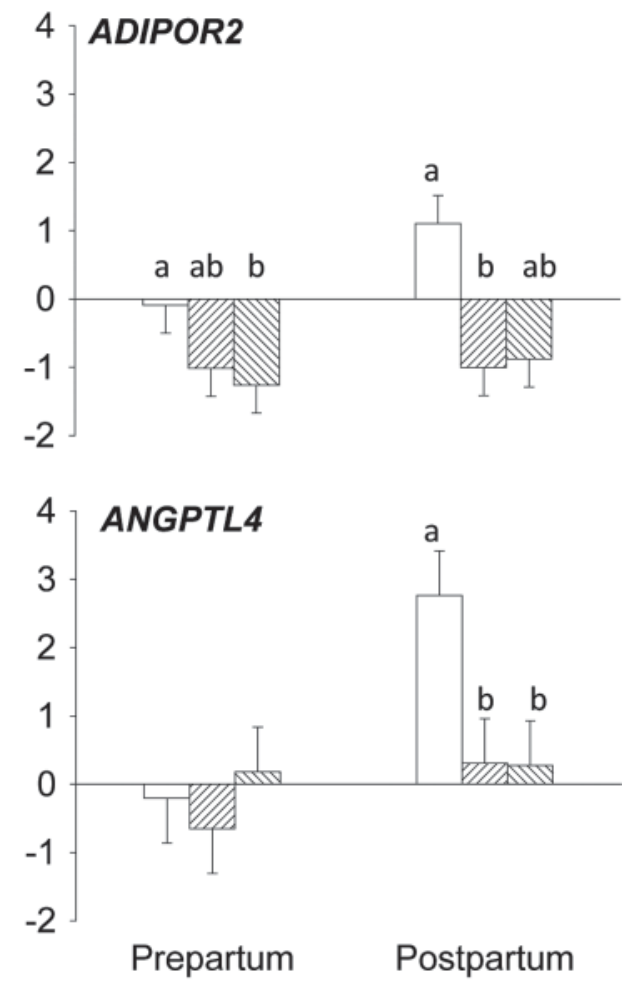

Figure 1. Expression of proteins secreted from adipose (ADIPOQ, LEP, ANGPTL4) or liver (ANGPTL4), and adiponectin receptor 2 (ADIPOR2) in liver of cows fed $(\mathrm{n}=5 /$ treatment) control, fish oil $(\mathrm{FO})$, or saturated lipid (SFAT) during the peripartal period. Different letters $(\mathrm{a}, \mathrm{b})$ denote significant interactions (diet $\times$ time, $P<0.05$ ). In adipose, mRNA abundance relative to $A C T B$ for $A D I P O Q, A N G P T L 4$, and $L E P$ was $0.8,8.6 \times 10^{-5}$, and 0.3 , respectively. In liver, mRNA abundance relative to UXT for ADIPOR2 and ANGPTL4 was 34.5 and 3.5, respectively.

served in the present study were within the range of values observed in the above-cited studies (Douglas et al., 2007; Petit et al., 2007; Andersen et al., 2008).

The responses observed in the concentration of fatty acids in blood plasma confirmed that supplemental FO resulted in an alteration of biohydrogenation of unsaturated fatty acids in the rumen (i.e., FO supplementation typically leads to lower 18:0 and higher trans-18:1 outflow from the rumen with the corresponding changes in their concentrations in ruminal fluid, duodenum, blood, and milk fat; Loor et al., 2005a,b). Fish oil also results in greater ruminal outflow of 20:5n3 and 22:6n3, which also increases their concentrations in plasma and milk (Loor et al., 2005a,b). Previous work also demonstrated increases in 16:0 and 18:0 in blood plasma prepartum due to saturated lipid supplementation around calving (Douglas et al., 2007; Petit et al., 2007; Andersen et al., 2008). However, this response may (Douglas et al., 2007) or may not (Andersen et al., 2008) be observed when supplementation stops postpartum. Although we did not measure adipose tissue fatty acid composition, judging from previous data (Douglas et al., 2007) it is 
likely that sustained supplementation with FO or SFAT led to incorporation of 16:0, 18:0, and very long-chain polyunsaturated fatty acids (PUFA) into adipose tissue. However, it also is likely that the dietary LCFA underwent metabolism within adipocytes (e.g., desaturation and elongation). Douglas et al. (2007) reported greater oleic acid in cows supplemented with energy booster than soybean oil.

Few studies have evaluated the biological activity of LCFA (including trans-18:1) in regard to PPAR; however, recent in vitro data with bovine mammary epithelial cells (Kadegowda et al., 2009) and kidney cells (Bionaz et al., 2011) have provided some evidence of the relative potency of different LCFA for activating PPAR $\alpha$ and PPAR $\gamma$. Evidence seems to suggest that 16:0, 18:0, and 20:5n3 are more potent than trans-18:1, 18:2n6, 18:3n3, and conjugated linoleic acids in eliciting effects on PPAR-regulated genes (Kadegowda et al., 2009; Bionaz et al., 2011). In the present study, feeding FO clearly led to marked increases in the systemic availability of $20: 5 \mathrm{n} 3,22: 5 \mathrm{n} 3$, and $22: 6 \mathrm{n} 3$, which accounted for approximately $9 \%$ of total plasma fatty acids after calving (Table 2). Unlike FO, feeding SFAT led to greater 16:0 and cis9-18:1 (probably derived from 18:0 desaturation in adipose). However, the likely fate of these fatty acids, regardless of treatment, would have been milk fat but also liver (as shown by Ballou et al., 2009) and potentially adipose.

\section{Adipogenic Networks and Their Control}

Data from one of our laboratories summarized in the review of Loor (2010) showed that several genes involved in anabolic pathways related to insulin and PPARG signaling [e.g., SREBF1, thyroid hormone responsive (THRSP), LPL, SCD, diacylglycerol $O$-acyltransferase 2 (DGAT2), phosphoenolpyruvate carboxykinase 1 (soluble; PCK1), and FASN] had greater expression at 2 wk prepartum (i.e., when insulin sensitivity is greater than postpartum) in cows overfed energy $(\sim 150 \%$ of energy requirements) relative to controls. Expression of lipogenic genes, however, decreases markedly after parturition (Sumner-Thomson et al., 2011). Insulin per se does not activate adipose PPARG but independently upregulates expression of genes associated with glucose transport, LCFA uptake, and lipogenesis partly through its direct effects on the transcription factor SREBF1 (Rosen and MacDougald, 2006; Postic et al., 2007). An additional well-established regulator of lipogenesis (mainly in liver) in nonruminants is MLX interacting protein-like (MLXIPL), formerly known as carbohydrate-responsive element-binding protein (ChREBP; Postic et al., 2007). Despite some overlap on the genes they control, both SREBF1 and MLXIPL are thought to independently regulate the concerted hepatic lipogenic responses to exogenous insulin or glucose in nonruminants (Postic et al., 2007). In the present study, relative mRNA abundance of PPARG (calculated as gene/UXT) and CEBPA was similar or greater than some of the well-established key lipogenic enzymes (e.g., DGAT2 and SCD; Tables 3 and 4), suggesting that both transcription regulators are important in the regulation of peripartal subcutaneous adipose tissue metabolism. Thus, as has been argued previously (Loor, 2010), the plasticity of peripartal bovine adipose tissue to changes in systemic hormones and specific nutrients could likely be under the control of these transcription regulators (i.e., PPARG, SREBF1, MLXIPL), their targets, and co-regulators/co-repressors. Because overfeeding energy to cows prepartum often leads to excessive internal fat deposition, it does not represent a useful strategy to target the PPARG network (Loor, 2010). The key point about PPARG activation via exogenous and endogenous ligands is that, in nonruminants, it enhances insulin sensitivity in adipose, thereby increasing glucose uptake and preferentially channeling it toward lipogenesis (Rosen and MacDougald, 2006). Thus, targeting adipose PPARG via nutrition (e.g., lipids or specific LCFA; Kadegowda et al., 2009; Bionaz et al., 2011) during the dry period could be a practical means of avoiding excessive fat deposition while maintaining/ enhancing insulin responsiveness after parturition.

The greater overall expression prepartum of the welldefined PPARG targets CEBPA, CEBPB, INSIG1, its heterodimerization partner $R X R A$, the key co-activator $C R E B B P$, the key transcription factor $K L F 5$, and the lipogenic enzymes DGAT2, FASN, LPIN1, and SCD (Table 3) was indicative of potential PPARG-network induction via dietary saturated LCFA and PUFA. In nonruminants, the concerted upregulation of those genes coordinates pre-adipocyte differentiation and lipogenesis (Rosen and MacDougald, 2006; Postic et al., 2007). The observed responses in gene expression seem to agree with previous data demonstrating greater lipogenic capacity in prepartal versus postpartal subcutaneous adipose tissue (McNamara et al., 1995). In contrast, despite the well-established decrease in lipogenic capacity in adipose tissue during the early postpartal period (McNamara et al., 1995), expression of several adipogenic transcription regulators in cows fed SFAT versus control or FO was not downregulated postpartum (e.g., CEBPA, CEBPB, KLF5, and RXRA; Table 3). Although expression of DGAT2, PCK1, and $S C D$ decreased overall postpartum, cows fed SFAT versus FO or control had greater expression of DGAT2 and $S C D$ postpartum (Table 3 ). It was surprising, however, to observe that feeding FO led to marked postpartal downregulation of $C E B P A, C E B P B$, and $R X R A$ along 
Table 4. Relative mRNA expression ${ }^{1}$ of lipogenic enzymes and inflammation-related genes in adipose tissue of cows fed $(\mathrm{n}=5 /$ treatment) control, fish oil (FO), or saturated lipid (SFAT) during the peripartal period

\begin{tabular}{|c|c|c|c|c|c|c|c|c|c|c|c|}
\hline Gene & Control & FO & SFAT & Control & FO & SFAT & SEM & $\mathrm{mRNA}^{2}$ & Diet & Time & $\mathrm{D} \times \mathrm{T}$ \\
\hline \multicolumn{12}{|c|}{ Lipogenic enzyme } \\
\hline DGAT2 & $-0.78^{\mathrm{b}}$ & $1.12^{\mathrm{a}}$ & $0.27^{\mathrm{ab}}$ & $-2.95^{\mathrm{b}}$ & $-5.57^{\mathrm{c}}$ & $-1.11^{\mathrm{a}}$ & 0.64 & 928 & 0.07 & 0.01 & 0.01 \\
\hline$F A B P 4$ & -0.38 & -0.50 & 0.05 & $-0.37^{\mathrm{a}}$ & $-1.91^{\mathrm{b}}$ & $-0.25^{\mathrm{a}}$ & 0.49 & 750 & 0.23 & 0.04 & 0.08 \\
\hline$F A S N$ & $-0.30^{\mathrm{b}}$ & $1.55^{\mathrm{a}}$ & $0.85^{\mathrm{ab}}$ & $-1.85^{\mathrm{a}}$ & $-4.92^{\mathrm{b}}$ & $-0.54^{\mathrm{a}}$ & 0.57 & 7,457 & 0.07 & 0.01 & 0.01 \\
\hline LPIN1 & $-0.79^{\mathrm{b}}$ & $1.16^{\mathrm{a}}$ & $0.15^{\mathrm{ab}}$ & $-1.44^{\mathrm{ab}}$ & $-2.20^{\mathrm{b}}$ & $-0.31^{\mathrm{a}}$ & 0.65 & 28.0 & 0.46 & 0.01 & 0.01 \\
\hline$S C D$ & $-0.61^{\mathrm{b}}$ & $1.14^{\mathrm{a}}$ & $0.33^{\mathrm{ab}}$ & $-3.38^{\mathrm{b}}$ & $-5.51^{\mathrm{b}}$ & $-1.14^{\mathrm{a}}$ & 0.58 & 2,766 & 0.06 & 0.01 & 0.01 \\
\hline \multicolumn{12}{|c|}{ Inflammation-related } \\
\hline$I K B K E$ & -0.13 & 1.19 & 0.82 & 1.16 & 2.15 & 1.37 & 0.31 & 1.1 & 0.04 & 0.01 & 0.19 \\
\hline IL6 & -1.13 & -1.22 & -1.21 & -0.55 & -0.98 & -0.37 & 0.29 & 1.2 & 0.64 & 0.01 & 0.44 \\
\hline NFKB1 & $-0.02^{\mathrm{b}}$ & $0.82^{\mathrm{a}}$ & $0.63^{\mathrm{a}}$ & $0.29^{\mathrm{b}}$ & $0.73^{\mathrm{a}}$ & $0.58^{\mathrm{ab}}$ & 0.13 & 5.3 & 0.01 & 0.36 & 0.02 \\
\hline$T B K 1$ & $-0.10^{\mathrm{b}}$ & $0.93^{\mathrm{a}}$ & $0.59^{\mathrm{a}}$ & $0.21^{\mathrm{b}}$ & $0.74^{\mathrm{a}}$ & $1.03^{\mathrm{a}}$ & 0.18 & 2.6 & 0.01 & 0.08 & 0.04 \\
\hline
\end{tabular}

${ }^{\mathrm{a}-\mathrm{c}}$ Means within rows with different superscript letters denote significant interactions due to diet $\times$ time $(\mathrm{D} \times \mathrm{T})(P<0.05)$.

${ }^{1}$ Expression data are relative to the prepartal control value as described in Materials and Methods.

${ }^{2}$ The mRNA abundance was calculated relative to $U X T$ (see Materials and Methods). Abundance $=1 / \mathrm{E}^{(\text {median } \Delta \mathrm{Ct})}$, where $\mathrm{E}=$ efficiency and $\mathrm{Ct}=$ cycle threshold.

with key enzymes such as LPL and SCD and the transcription regulator $S R E B F 1$. A clear explanation for those effects is not readily apparent and, to some extent, would appear counterintuitive because in nonruminants, 20:5n3 and 22:6n 3 (at least in vitro) are PPARG activators (Krey et al., 1997). Both 20:5n3 and 22:6n 3 , however, are potent inhibitors of hepatic lipogenesis but potent activators of fatty acid oxidation via PPARo (Jump, 2008). Previous in vitro data with bovine mammary cells found marked downregulation of SREBF1, SCD, and $L P L$ with exogenous 20:5n3 (Kadegowda et al., 2009). Thus, it could be possible that in ruminants, both 20:5n3 and 22:6n 3 inhibit the PPARG network.

The fact that $P C K 1$ expression postpartum was similar in cows fed the control or SFAT suggests that glyceroneogenesis was not impaired by supplemental SFAT, thus ensuring availability of glycerol for reesterification of fatty acids (Nye et al., 2008). A previous in vitro study with bovine mammary cells showed that saturated LCFA (16:0, 18:0) was more potent in inducing upregulation of lipogenic genes under control of PPARG including SCD (Kadegowda et al., 2009). Another in vitro study showed that $20: 5 \mathrm{n} 3$ was as potent as 16:0 and 18:0 in inducing several PPAR $\alpha$ targets in bovine kidney cells (Bionaz et al., 2011). In fact, trans10-18:1, trans11-18:1, CLA, or 18:2 seem to be weak effectors of PPAR-regulated gene networks (Kadegowda et al., 2009; Bionaz et al., 2011). Taken together, our data suggest that dietary SFAT availability (SFAT is rich in 16:0 and 18:0) during the peripartal period may have allowed adipose tissue to retain some pro-adipogenic features even after calving. This is an intriguing possibility, given the well-established hormonal and transcriptional (Sumner-Thomson et al., 2011) adaptations in the postpartal period that promote lipolysis. The marked decrease in expression of most adipogenic transcription regulators and lipogenic enzymes after parturition (Tables 2 and 3 ) likely constitutes an important mechanism for the decrease in adipocyte diameter, volume, and depot mass in early postpartal cows (McNamara et al., 1995).

\section{Nuclear Receptor Co-Activators and Co-Repressors}

In nonruminant in vitro systems (Gao et al., 2005; Rosen and MacDougald, 2006), the use of more advanced techniques (e.g., chromatin immunoprecipitation) has revealed a landscape where co-activators and co-repressors are often simultaneously recruited to gene promoters after NR activation, with the ensuing recruitment of RNA polymerase II followed by transcription initiation. The binding of co-activators and co-repressors to the promoter DNA oscillates and the interaction of each co-activator with the promoter often exhibits different patterns. For example, after tumor necrosis factor (TNF) binding in HEK293 cells, the NCOA1 signal was increased gradually but the NCOA2 signal was decreased almost immediately, suggesting replacement of NCOA2 by NCOA1 (Gao et al., 2005). Such a scenario could indicate that a given co-activator may be required for inducible gene transcription and another for basal gene transcription (Gao et al., 2005).

The fact that the co-repressor NCOR2 was upregulated with dietary lipid agrees with data from nonruminants showing that its recruitment to the $P P A R G$ $R X R A$ heterodimer upon PPARG activation occurs during adipogenesis (Samarasinghe et al., 2009). At 
least in vitro, availability of ligand and recruitment of co-activators during PPARG activation seem to override the negative effect of $N C O R 2$ on adipogenesis (Samarasinghe et al., 2009); thus, the greater abundance of $C R E B B P$ and $R X R A$ in response to SFAT and FO would have served to maintain the ability of the adipocyte to differentiate and accrete lipid.

A seemingly paradoxical response in the context of adipogenic regulators was the greater prepartal expression of NRIP1 in cows fed FO and SFAT versus control because in nonruminants this co-repressor has been shown in some instances to decrease adipogenesis and dampen the tissue's sensitivity to insulin (Fritah et al., 2010). However, it has become evident that NRIP1 also can serve as a co-activator in metabolic tissues. For example, in rodent liver, NRIP1 can activate liverX-receptor (LXR) and its target genes $S R E B F 1$ and FASN (Fritah et al., 2010), and a progressive increase in NRIP1 expression occurred during rodent preadipocyte differentiation in vitro (Leonardsson et al., 2004). Thus, at least in nonruminants, NRIP1 seems to play dual roles in metabolic tissues but the precise mechanisms driving its co-activator role remain elusive. The fact that relative mRNA abundance of NRIP1 was markedly lower than co-activators (e.g., CREBBP, $R X R A$ ) seems to suggest that it may play a minor role as co-repressor/co-activator in s.c. bovine adipose tissue.

Quite surprisingly, given the marked adipose tissue catabolic environment postpartum, the expression of 4 co-activators studied was greater postpartum with dietary SFAT than FO (Table 3). Further, relative mRNA abundance of the co-activators was greater than co-repressors. We are unaware of previous studies evaluating PPAR co-activator expression in adipose due to dietary fat, but the postpartal responses observed in these genes due to SFAT (Tables 3 and 4) coupled with changes in $S C D, D G A T 2, C E B P A, C E B P B$, and $R X R A$, and the fact that $C R E B B P$ remained elevated throughout the study, are suggestive of a concerted adipogenic mechanism driven, at least in part, by greater SFAT availability. Because, in our study, cows were fed the treatment diets continuously through $10 \mathrm{~d}$ postpartum, the tissues were exposed to a sustained dose of LCFA; thus, transcriptional responses are likely tightly linked to long-term ligand availability. It remains to be determined if under such a scenario the dynamics of co-repressor and co-activator binding to target DNA would oscillate as in the short-term in vitro studies conducted in nonruminants.

The NRIP1 upregulation postpartum with SFAT might have been linked with a pro-lipogenic (Fritah et al., 2010) or pro-adipogenic response (Leonardsson et al., 2004). However, both seem unlikely, given the de- crease in FASN from prepartal levels (Table 3) and the fact that fibroblasts from NRIP1-null mice were able to differentiate just as those from wild-type mice (Leonardsson et al., 2004). What seems evident from previous rodent studies is that NRIP1 is required for expression of genes associated with energy metabolism (e.g., uncoupling protein 1 , carnitine palmitoyl-transferase 1 ) partly under control of $\beta$-adrenergic stimulation and PPAR $\alpha / \delta$ (Leonardsson et al., 2004). Judging from the upregulation of TBK1 and NFKB1 in our study (Table 3 ), an alternative explanation for NRIP1 upregulation with dietary fat supplementation both pre- and postpartum might be that it was triggered by a local pro-inflammatory response induced by LCFA and the hormonal/physiological environment characteristic of the peripartal period. In nonruminant immune cells, NRIP1 interacts with the $\mathrm{NF}_{k} \mathrm{~B}$ subunit RelA and the transcriptional co-activator CREBBP via the $\mathrm{NH}_{2}$-terminal domain of NRIP1 (Fritah et al., 2010). Immune cells devoid of NRIP1 had markedly lower expression of IL6, IL1B, TNF, and IFNB1 (fibroblast isoform) even when challenged with LPS (Zschiedrich et al., 2008). Whether NRIP1 has similar functions in bovine adipose during the peripartal period will have to be determined in future studies. Microarray studies, however, indicate a large degree of differential expression of immune-related genes in peripartal adipose and liver tissue (Loor, 2010; Sumner-Thomson et al., 2011).

The fact that SFAT and FO resulted in sustained upregulation of several co-activators after parturition and their relative mRNA abundance was much greater than co-repressors is suggestive of their dominance in regulating transcription after NR activation. These responses also are suggestive of the maintenance of a pro-adipogenic phenotype despite the marked catabolic stimuli that ensues upon parturition. Lipogenic capacity of adipose tissue decreases markedly after calving (McNamara et al., 1995); thus, our observations are somewhat non-intuitive. However, recent work from one of our laboratories has revealed a clear upregulation in expression of lipogenic genes and transcription regulators between 7 and $21 \mathrm{~d}$ postpartum (Ji et al., 2011), which seems to confirm at the transcriptional level that the adipogenic/lipogenic program may be active despite the lipolytic hormonal environment. Clearly, other factors (e.g., substrate availability, surge in growth hormone) may be limiting the ability of the adipose tissue to accrete lipid soon after parturition.

\section{Adipokines and Growth Factors}

Work with NCOR heterozygous mice has revealed that its expression in vivo is required to control for over-abundance of preadipocytes in s.c. adipose tissue 
and also to upregulate the expression and release of LEP (Sutanto et al., 2010; i.e., a putative mechanism to control both adipose differentiation and lipid filling but also food intake via LEP). Despite the upregulation of NCOR2 (Table 2), we did not observe prepartal effects of diet on expression of $L E P$ or $A D I P O Q$ but we found a marked decrease in the postpartal expression of both adipokines in cows fed FO versus SFAT (Figure 1) without changes in NCOR2. A recent study reported no change in $A D I P O Q$ and a decrease in $L E P$ in s.c. adipose tissue after parturition (Lemor et al., 2009), which is supported by data from the control cows in the present study. The reduction of $L E P$ in adipose tissue and blood postpartum is correlated with lower blood insulin (Block et al., 2003) and blood leptin. Because of its adipose tissue origin and the observed decrease in mRNA expression, lower blood $A D I P O Q$ postpartum would be expected.

Regardless of changes in circulating LEP or ADIPOQ, downstream metabolic effects of these adipokines may be more a function of receptor expression in target tissues (e.g., cows overfed energy prepartum and with greater blood NEFA concentrations postpartum had a gradual increase in liver ADIPOR2 expression between pre- and postpartum; Loor et al., 2006). Rodent studies have shown that ADIPOQ and a functional liverspecific ADIPOR2 are involved in regulation of hepatic fatty acid oxidation (Yamauchi et al., 2007). In our study, pre- and postpartum expression of ADIPOR2 in liver (Figure 1) was lower due to fat supplementation but was greater in control cows after parturition as observed previously (Loor et al., 2006). Because of the lack of effect of diet on NEFA, glucose, BHBA, and liver triacylglycerol concentrations (Table 1), it seems apparent in the case of lipid supplementation that the preferential channeling of LCFA for mammary utilization postpartum decreased flux to liver, thus lessening the burden on LCFA oxidation pathways and sparing some LCFA for adipose tissue metabolism.

Although the main objective of the current study was to focus on adipose transcriptomics, it is intuitive that dietary lipids might also have affected liver metabolic gene expression (Carriquiry et al., 2009). In that context, it was previously proposed that adaptations in hepatic ADIPOR2 expression, if they translated into more protein, would be one adaptation to allow for adiponectin action (via PPAR $\alpha$ ) to stimulate LCFA oxidation (Loor et al., 2006). Hepatic PPAR $\alpha$ was not the subject of the present study but we observed greater postpartal expression of the target gene angiopoietinlike 4 (ANGPTL4) in both adipose and liver. In rodents, ANGPTL4 is a secreted protein produced primarily in adipose tissue but also liver that inhibits LPL activity, enhances lipolysis, and was recently shown to represent a novel positive acute-phase protein (i.e., a protein secreted in response to infection, inflammation, or disease; Lu et al., 2010). Mice injected with LPS or zymosan had greater expression of ANGPTL4 in adipose, muscle, and liver tissue and corresponding increases of the protein in blood serum (Lu et al., 2010).

In the present study, dietary SFAT resulted in greater postpartal ANGPTL4 in adipose but in liver its expression was approximately 3 -fold greater in control cows (Figure 1). It was recently demonstrated that bovine liver expresses ANGPTL4 and that its expression is markedly upregulated during undernutrition and negative energy balance early postpartum (Loor et al., 2007), a response that has been well-described in rodents. Ruminant adipose and gastrointestinal tract tissue also express ANGPTL4 (Mamedova et al., 2010). Recent work has provided evidence that bovine $A N G$ $P T L 4$, as in rodents, might be regulated by PPAR $\alpha$ activation as shown by its marked upregulation in bovine kidney cells incubated with the PPAR $\alpha$ agonist $\mathrm{Wy}$ 14,643 (Bionaz et al., 2011). More importantly in the context of the present study, results also indicated that both 16:0 and 18:0 elicited the strongest upregulation of ANGPTL4 (Bionaz et al., 2011). The responses we observed in both adipose and liver postpartum might have been related to an inflammatory response, which often characterizes the early postpartal period (Bertoni et al., 2008). From the standpoint of adipose tissue, however, our data seem to confirm rodent studies ( $\mathrm{Lu}$ et al., 2010) showing that adipocytes challenged with LPS, TNF, IL1B, or IFN- $\gamma$ resulted in upregulation of ANGPTL4 expression. Thus, adipose ANGPTL4 synthesis postpartum could represent an additional control molecule for metabolic adaptations to the onset of lactation.

\section{CONCLUSIONS}

At the amounts fed in the current study $(\sim 1.5 \%$ to $\sim 1.9 \%$ of DM), dietary long-chain PUFA and saturated LCFA (16:0 and 18:0 primarily) during the last $21 \mathrm{~d}$ of the prepartal period were equally effective in upregulating (except for SREBF1) the adipose tissue PPARGgene network, which encompassed not only transcription regulators and co-regulators but several wellknown adipogenic/lipogenic enzymes that coordinate the process of lipogenesis and esterification. Although postpartal expression of these networks decreased to various extents (regardless of prepartal diet) compared with saturated LCFA, supplemental FO at approximately $1.5 \%$ of DMI through 10 DIM was ineffective in sustaining the response observed in the prepartal period. The fact that DMI and milk production were similar in control and SFAT-fed cows, yet transcrip- 
tion regulator expression in lipid-fed cows was greater postpartum, points at molecular adaptations in those animals that may have allowed them to achieve high milk production as well as maintain the ability of the adipocytes to accrete lipid. The lack of upregulation with lipid supplementation of prepartal SREBF1 expression, a well-established insulin-regulated lipogenic transcription factor in nonruminants, coupled with the observed expression patterns of PPARG-regulated gene networks are suggestive of an insulin-independent adipogenic regulatory mechanism responsive to LCFA.

\section{ACKNOWLEDGMENTS}

Eduardo Schmitt was supported by a fellowship from Coordenação de Aperfeiçoamento de Pessoal de Nível Superior from the Brazilian Ministry of Education. The help of Daniel Graugnard and Sonia Moisa (graduate research assistants, University of Illinois, Urbana) during portions of this work is greatly appreciated. Partial support for the gene expression work was provided by Section 1433 Animal Health and Disease funds under project ILLU-538-961 (National Institute of Food and Agriculture, Washington, DC).

\section{REFERENCES}

Andersen, J. B., C. Ridder, and T. Larsen. 2008. Priming the cow for mobilization in the periparturient period: Effects of supplementing the dry cow with saturated fat or linseed. J. Dairy Sci. 91:1029-1043.

Ballou, M. A., R. C. Gomes, S. O. Juchem, and E. J. DePeters. 2009. Effects of dietary supplemental fish oil during the peripartum period on blood metabolites and hepatic fatty acid compositions and total triacylglycerol concentrations of multiparous Holstein cows. J. Dairy Sci. 92:657-669.

Bertoni, G., E. Trevisi, X. Han, and M. Bionaz. 2008. Effects of inflammatory conditions on liver activity in puerperium period and consequences for performance in dairy cows. J. Dairy Sci. 91:3300-3310.

Bionaz, M., and J. J. Loor. 2011. Gene networks driving bovine mammary protein synthesis during the lactation cycle. Bioinform. Biol. Insights 5:83-98.

Bionaz, M., B. J. Thering, and J. J. Loor. 2011. Fine metabolic regulation in ruminants via nutrient/gene interactions: Saturated longchain fatty acids increase expression of genes involved in lipid metabolism and immune response partly through PPAR $\alpha$ activation. Br. J. Nutr. doi:10.1017/S0007114511002777.

Block, S. S., R. P. Rhoads, D. E. Bauman, R. A. Ehrhardt, M. A. McGuire, B. A. Crooker, J. M. Griinari, T. R. Mackle, W. J. Weber, M. E. Van Amburgh, and Y. R. Boisclair. 2003. Demonstration of a role for insulin in the regulation of leptin in lactating dairy cows. J. Dairy Sci. 86:3508-3515.

Carriquiry, M., W. J. Weber, S. C. Fahrenkrug, and B. A. Crooker. 2009. Hepatic gene expression in multiparous Holstein cows treated with bovine somatotropin and fed n-3 fatty acids in early lactation. J. Dairy Sci. 92:4889-4900.

Chau, T.-L., R. Gioia, J.-S. Gatot, F. Patrascu, I. Carpentier, J.-P. Chapelle, L. O'Neill, R. Beyaert, J. Piette, and A. Chariot. 2008. Are the IKKs and IKK-related kinases TBK1 and IKK- $\varepsilon$ similarly activated? Trends Biochem. Sci. 33:171-180.

Douglas, G. N., J. Rehage, A. D. Beaulieu, A. O. Bahaa, and J. K. Drackley. 2007. Prepartum nutrition alters fatty acid composition in plasma, adipose tissue, and liver lipids of periparturient dairy cows. J. Dairy Sci. 90:2941-2959.

Fritah, A., M. Christian, and M. G. Parker. 2010. The metabolic coregulator RIP140: An update. Am. J. Physiol. Endocrinol. Metab. 299:E335-E340

Gao, Z., P. Chiao, X. Zhang, M. A. Lazar, E. Seto, H. A. Young, and J. Ye. 2005. Coactivators and corepressors of NF- $\kappa$ B in I $\kappa$ B alpha gene promoter. J. Biol. Chem. 280:21091-21098.

Heravi Moussavi, A. R., R. O. Gilbert, T. R. Overton, D. E. Bauman, and W. R. Butler. 2007. Effects of feeding fish meal and n-3 fatty acids on milk yield and metabolic responses in early lactating dairy cows. J. Dairy Sci. 90:136-144.

Hsia, E. Y., M. L. Goodson, J. X. Zou, M. L. Privalsky, and H. W. Chen. 2010. Nuclear receptor coregulators as a new paradigm for therapeutic targeting. Adv. Drug Deliv. Rev. 62:1227-1237.

Invernizzi, G., B. J. Thering, M. A. McGuire, G. Savoini, and J. J. Loor. 2010. Sustained upregulation of stearoyl-CoA desaturase in bovine mammary tissue with contrasting changes in milk fat synthesis and lipogenic gene networks caused by lipid supplements. Funct. Integr. Genomics 10:561-575.

Ji, P., J. S. Osorio, J. K. Drackley, and J. J. Loor. 2011. Physiological and transcriptional adaptations in adipose tissue of dairy cows in response to prepartal plane of dietary energy. J. Dairy Sci. 93(ESuppl. 1):77.

Jump, D. B. 2008. N-3 polyunsaturated fatty acid regulation of hepatic gene transcription. Curr. Opin. Lipidol. 19:242-247.

Kadegowda, A. K. G., M. Bionaz, L. S. Piperova, R. A. Erdman, and J. J. Loor. 2009. Peroxisome proliferator-activated receptor- $\gamma$ activation and long-chain fatty acids alter lipogenic gene networks in bovine mammary epithelial cells to various extents. J. Dairy Sci. 92:4276-4289.

Krey, G., O. Braissant, F. L'Horset, E. Kalkhoven, M. Perroud, M. G. Parker, and W. Wahli. 1997. Fatty acids, eicosanoids, and hypolipidemic agents identified as ligands of peroxisome proliferator-activated receptors by coactivator-dependent receptor ligand assay. Mol. Endocrinol. 11:779-791.

Lemor, A., A. Hosseini, H. Sauerwein, and M. Mielenz. 2009. Transition period-related changes in the abundance of the mRNAs of adiponectin and its receptors, of visfatin, and of fatty acid binding receptors in adipose tissue of high-yielding dairy cows. Domest. Anim. Endocrinol. 37:37-44.

Leonardsson, G., J. H. Steel, M. Christian, V. Pocock, S. Milligan, J. Bell, P. W. So, G. Medina-Gomez, A. Vidal-Puig, R. White, and M. G. Parker. 2004. Nuclear receptor corepressor RIP140 regulates fat accumulation. Proc. Natl. Acad. Sci. USA 101:8437-8442.

Loor, J. J. 2010. Genomics of metabolic adaptations in the peripartal cow. Animal 4:1110-1139.

Loor, J. J., H. M. Dann, N. A. Guretzky, R. E. Everts, R. Oliveira, C. A. Green, N. B. Litherland, S. L. Rodriguez-Zas, H. A. Lewin, and J. K. Drackley. 2006. Plane of nutrition prepartum alters hepatic gene expression and function in dairy cows as assessed by longitudinal transcript and metabolic profiling. Physiol. Genomics $27: 29-41$.

Loor, J. J., R. E. Everts, M. Bionaz, H. M. Dann, D. E. Morin, R. Oliveira, S. L. Rodriguez-Zas, J. K. Drackley, and H. A. Lewin. 2007. Nutrition-induced ketosis alters metabolic and signaling gene networks in liver of periparturient dairy cows. Physiol. Genomics 32:105-116.

Loor, J. J., A. Ferlay, A. Ollier, K. Ueda, M. Doreau, and Y. Chilliard. 2005a. High-concentrate diets and polyunsaturated oils alter trans and conjugated isomers in bovine rumen, blood, and milk. J. Dairy Sci. 88:3986-3999.

Loor, J. J., K. Ueda, A. Ferlay, Y. Chilliard, and M. Doreau. 2005b. Intestinal flow and digestibility of trans fatty acids and conjugated linoleic acids (CLA) in dairy cows fed a high-concentrate diet supplemented with fish oil, linseed oil, or sunflower oil. Anim. Feed Sci. Technol. 119:203-225.

Lu, B., A. Moser, J. K. Shigenaga, C. Grunfeld, and K. R. Feingold. 2010. The acute phase response stimulates the expression of angiopoietin like protein 4. Biochem. Biophys. Res. Commun. 391:1737-1741. 
Mamedova, L. K., K. Robbins, B. J. Johnson, and B. J. Bradford. 2010. Tissue expression of angiopoietin-like protein 4 in cattle. J. Anim. Sci. 88:124-130.

Mattos, R., C. R. Staples, A. Arteche, M. C. Wiltbank, F. J. Diaz, T. C. Jenkins, and W. W. Thatcher. 2004. The effects of feeding fish oil on uterine secretion of $\mathrm{PGF}_{2 \alpha}$, milk composition, and metabolic status of periparturient Holstein cows. J. Dairy Sci. 87:921-932.

McNamara, J. P., J. H. Harrison, R. L. Kincaid, and S. S. Waltner. 1995. Lipid metabolism in adipose tissue of cows fed high fat diets during lactation. J. Dairy Sci. 78:2782-2796.

Nye, C., J. Kim, S. C. Kalhan, and R. W. Hanson. 2008. Reassessing triglyceride synthesis in adipose tissue. Trends Endocrinol. Metab. 19:356-361.

Petit, H. V., M. F. Palin, and L. Doepel. 2007. Hepatic lipid metabolism in transition dairy cows fed flaxseed. J. Dairy Sci. 90:47804792.

Postic, C., R. Dentin, P.-D. Denechaud, and J. Girard. 2007. ChREBP, a transcriptional regulator of glucose and lipid metabolism. Annu. Rev. Nutr. 27:179-192.

Rosen, E. D., and O. A. MacDougald. 2006. Adipocyte differentiation from the inside out. Nat. Rev. Mol. Cell Biol. 7:885-896.

Samarasinghe, S. P., M. M. Sutanto, A. M. Danos, D. N. Johnson, M. J. Brady, and R. N. Cohen. 2009. Altering PPAR $\gamma$ ligand selectivity impairs adipogenesis by thiazolidinediones but not hormonal inducers. Obesity (Silver Spring) 17:965-972.

Smith, K. L., W. R. Butler, and T. R. Overton. 2009. Effects of prepartum 2,4-thiazolidinedione on metabolism and performance in transition dairy cows. J. Dairy Sci. 92:3623-3633.

Smith, K. L., S. E. Stebulis, M. R. Waldron, and T. R. Overton. 2007. Prepartum 2,4-thiazolidinedione alters metabolic dynamics and dry matter intake of dairy cows. J. Dairy Sci. 90:3660-3670.

Sumner-Thomson, J. M., J. L. Vierck, and J. P. McNamara. 2011. Differential expression of genes in adipose tissue of first-lactation dairy cattle. J. Dairy Sci. 94:361-369.

Sutanto, M. M., K. K. Ferguson, H. Sakuma, H. Ye, M. J. Brady, and R. N. Cohen. 2010. The silencing mediator of retinoid and thyroid hormone receptors (SMRT) regulates adipose tissue accumulation and adipocyte insulin sensitivity in vivo. J. Biol. Chem. 285:18485-18495.

Tramontana, S., M. Bionaz, A. Sharma, D. E. Graugnard, E. A. Cutler, P. Ajmone-Marsan, W. L. Hurley, and J. J. Loor. 2008. Internal controls for quantitative polymerase chain reaction of swine mammary glands during pregnancy and lactation. J. Dairy Sci. 91:3057-3066.

Wathes, D. C., Z. Cheng, W. Chowdhury, M. A. Fenwick, R. Fitzpatrick, D. G. Morris, J. Patton, and J. J. Murphy. 2009. Negative energy balance alters global gene expression and immune responses in the uterus of postpartum dairy cows. Physiol. Genomics 39:1-13.

Whitlock, L. A., D. J. Schingoethe, A. R. Hippen, K. F. Kalscheur, R. J. Baer, N. Ramaswamy, and K. M. Kasperson. 2002. Fish oil and extruded soybeans fed in combination increase conjugated linoleic acids in milk of dairy cows more than when fed separately. J. Dairy Sci. 85:234-243.

Yamauchi, T., Y. Nio, T. Maki, M. Kobayashi, T. Takazawa, M. Iwabu, M. Okada-Iwabu, S. Kawamoto, N. Kubota, T. Kubota, Y. Ito, J. Kamon, A. Tsuchida, K. Kumagai, H. Kozono, Y. Hada, H. Ogata, K. Tokuyama, M. Tsunoda, T. Ide, K. Murakami, M. Awazawa, I. Takamoto, P. Froguel, K. Hara, K. Tobe, R. Nagai, K. Ueki, and T. Kadowaki. 2007. Targeted disruption of AdipoR1 and AdipoR2 causes abrogation of adiponectin binding and metabolic actions. Nat. Med. 13:332-339.

Yu, S., and J. K. Reddy. 2007. Transcription coactivators for peroxisome proliferator-activated receptors. Biochim. Biophys. Acta 1771:936-951.

Zschiedrich, I., U. Hardeland, A. Krones-Herzig, M. Berriel Diaz, A. Vegiopoulos, J. Müggenburg, D. Sombroek, T. G. Hofmann, R. Zawatzky, X. Yu, N. Gretz, M. Christian, R. White, M. G. Parker, and S. Herzig. 2008. Coactivator function of RIP140 for NFאB/ RelA-dependent cytokine gene expression. Blood 112:264-276. 